\begin{tabular}{|l|l|l||}
\hline \multicolumn{2}{|c|}{ PublisherInfo } \\
\hline \hline PublisherName & $:$ & BioMed Central \\
\hline \hline PublisherLocation & $:$ & London \\
\hline \hline PublisherImprintName & $:$ & BioMed Central \\
\hline \hline
\end{tabular}

\title{
Nanotubes link immune cells
}

\begin{tabular}{|l|l|l||}
\hline \multicolumn{2}{|c|}{ ArticleInfo } \\
\hline \hline ArticleID & $:$ & 5035 \\
\hline \hline ArticleDOI & $:$ & $10.1186 /$ gb-spotlight-20050920-01 \\
\hline \hline ArticleCitationID & $:$ & spotlight-20050920-01 \\
\hline \hline ArticleSequenceNumber & $:$ & 98 \\
\hline \hline ArticleCategory & $:$ & Research news \\
\hline ArticleFirstPage & $:$ & 1 \\
\hline \hline ArticleLastPage & $:$ & 3 \\
\hline \hline & & RegistrationDate : 2005-9-20 \\
\hline ArticleHistory & $:$ & OnlineDate \\
\hline \hline ArticleCopyright & $:$ & BioMed Central Ltd2005-9-20 \\
\hline \hline ArticleGrants & $:$ & \\
\hline \hline ArticleContext & $:$ & 130595511 \\
\hline \hline
\end{tabular}


A number of types of immune cells communicate via a naturally occurring network of nanotubes, investigators report today in this month's Immunity. These findings suggest that nanotubes could serve as a third form of intercellular communication, distinct from gap junctions and synapses, and faster than secreted chemical signals alone, co-author Simon Watkins at the University of Pittsburgh School of Medicine told The Scientist.

"We think the cells make these connections so that they can work in a coordinated fashion to collect antigens from pathogens rather than working as individuals. This would seem to make the likelihood of successful delivery of the antigen to a distant lymph node much more likely," Watkins said in an email.

These findings could serve as a "good solution" for the "puzzles" plaguing many different fields in research, said Hans-Hermann Gerdes at the University of Bergen in Norway, who did not participate in this study. "What you would like to see now is whether this is a general mechanism used by many different cell types, whether there are other types of signals transferred, whether there is gating of signals, are there pathologies that impair this signaling."

Watkins and co-author Russell Salter stumbled upon this network of nanotubes while studying how dendritic cells and macrophages responded to E. coli fragments. They found that dendritic cells tend to respond to the fragments with calcium fluxes. But when the scientists accidentally poked one macrophage with a microinjection tip, they saw calcium fluxes from its neighboring macrophages. They noticed the same after poking dendritic cells, but not after poking fibroblasts or HeLa cells.

Since calcium did not spread evenly in a wave from poked cells, the researchers suspected signals were traveling via a physical network connecting the cells. Differential interference contrast imaging revealed up to 75 nanotubes connecting macrophages, and captured calcium traveling down nanotubes from stimulated cells toward connected cells. Nanotubes measured between 35 and 200 nanometers across and up to 100 microns long. Live-cell time-lapse confocal microscopy showed the connections form and disappear frequently between cells over spans of several minutes. The plasma membrane appeared contiguous along the nanotubes, "and we could show actin was present inside the nanotubes," Salter told The Scientist.

Nanotubes linking cells were first reported in Drosophila in 1999, recently in vertebrate neural cells by Gerdes his colleagues, and in immune cells by multiple groups. "This is the first paper that has gone the distance of showing that they can actually relay a signal," Michael Dustin at New York University, who did not participate in this study, told The Scientist in an email.

Signals through nanotubes traveled up to 500 microns from the initial point of stimulation at up to 35 microns per second. As a result, these nanotubes could allow for communication between cells in the immune system that travels faster than would be possible with secretion of cytokines alone, Salter said.

Macrophages by themselves don't appear able to respond to E. coli fragments. But when in mixed culture, dendrites appear to respond first and transmit the signal to neighboring macrophages, suggesting that different cell types can use these networks to respond to an antigen or other stimuli that one cell type, working alone, might not otherwise respond to or perceive. 
"If antigens are transferred through these tubules, a question would be are the full antigens distributed, or do they have to be processed to smaller pieces," Salter said. "Possibly some viruses could travel down these tubules. We don't know if HIV could. That's something we'd like to get at."

Future research needs to confirm these nanotubes are not simply a reaction from cells under stress in culture, something in vivo experiments could rule out, Gerdes noted. Unfortunately, this may be nearly impossible to determine with current technology, Salter said.

\section{References}

1. S.C. Watkins and R.D. Salter. "Functional connectivity between immune cells mediated by tunneling nanotubules," Immunity, 23:309-18, September 2005., [http://www.immunity.com]

2. Simon Watkins, [http://www.cbp.pitt.edu/faculty/watkins.html]

3. Hans-Hermann Gerdes, [http://www.uib.no/med/biomed/research/gerdes]

4. Russell Salter, [http://www.gradbiomed.pitt.edu/immunology/faculty.asp?ID=39]

5. T. Kornberg. "Pictures in cell biology," Trends in Cell Biology, 9:434, November 1999.

6. D. Secko. "Nanotubules shuttle organelles," The Scientist, February 13, 2004., [http://www.thescientist.com/news/20040213/01]

7. A. Rustom. "Nanotubular highways for intercellular organelle transport," Science, 303:1007-10, February 13, 2004.

8. Michael Dustin, [http://saturn.med.nyu.edu/research/mp/dustinlab/members.html]

9. J. Roberts. "Dissecting the immunological synapse," The Scientist, May 5, 2003., [http://www.thescientist.com/2003/05/05/28/1]

This PDF file was created after publication. 